Received: 25/06/2018

\title{
The Effect of Concrete-Pictorial-Abstract Strategy toward Students' Mathematical Conceptual Understanding and Mathematical Representation on Fractions
}

\section{Made Ari Purwadi}

B.Ed., Department of Mathematics Education, University of Pendidikan Ganesha, imadearipurwadi@gmail.com

\section{Gusti Putu Sudiarta}

Prof., Department of Mathematics Education, University of Pendidikan Ganesha, gussudiarta@undiksha.ac.id

\section{Nengah Suparta}

Prof., Department of Mathematics Education, University of Pendidikan Ganesha, nengah.suparta@undiksha.ac.id

This study aimed at: (1) determining whether the Concrete-Pictorial-Abstract (CPA) strategy has a positive effect on students' mathematical conceptual understanding (MCU) and students' mathematical representation (MR) on fractions; (2) describing how CPA strategy can improve students' MCU and students' MR on fractions. This research used a mixed method with simultaneous strategy. Sixty-six students participated in the test control group during the quantitative phase. The experimental group employed the CPA strategy teaching method and their test occurred during eight meetings. The descriptive approach was used during the qualitative phase. The members of the experimental group were chosen with certain characteristics in mind. The quantitative data which included MCU and MR were collected using a narrative format. The qualitative data were; (a) students' responses to CPA strategy, (b) group discussion activities, and (c) student products which were collected using (a) thorough interviews, (b) observations collected on forms, and (c) documentation of behaviors. The quantitative data were analyzed using one tailed of MANOVA test with significance level of $5 \%$. The qualitative data were analyzed in 3 stages; (a) data reduction, (b) data presentation, and (c) data verification.

Keywords: concrete-pictorial-abstract strategy, fractions, conceptual understanding, mathematical representation, fractions

Citation: Purwadi, I M. A., Sudiarta, I G. P., \& Suparta, I N. (2019). The Effect of Concrete-PictorialAbstract Strategy toward Students' Mathematical Conceptual Understanding and Mathematical Representation on Fractions. International Journal of Instruction, 12(1), 1113-1126. https://doi.org/10.29333/iji.2019.12171a 


\section{INTRODUCTION}

Fractions are important to understand to master more complex mathematical concepts (Khuriyati, 2015; Prayitno \& Wulandari, 2015; Sadra, 2013; Suharta, 2004; Zabeta at al., 2015). Fractions are units that compose a whole. Thus, equal parts are inherentto the understanding of fractions (Sadra, 2013; Suharta, 2004). A lot of real life problems involve fractions as an integral part of reaching a solution (Suharta, 2004).

Unfortunately, many students struggle to understand fractions (Edo \& Samo, 2017; Wijaya, 2017; Zabeta et al., 2015). Students misunderstand the concept of fractions and thereby often make mistakes when trying to solve problems involving them (Sudiana et al., 2006; Zabeta et al., 2015). Some of the most common mistakes include: (1) making errors when drawing pictures of fractions; (2) accidentally changing a mixed fraction into a proper fraction; (3) transforming fraction into a decimal or percent; (4) comparing two or more fractions with different denominators; (5) adding and subtracting fractions with different denominators; (6) multiplying and dividing fractions (Sudiana et al., 2006; Zabeta et al., 2015).

Students' difficulties in understanding fractions concept are rooted in their lack of MR ability (Suharta, 2004). Mathematical representation on fractions plays an important role in improving the understanding of fractions concepts as well as in interpreting and solving problems involving fractions (Supandi et al., 2018). In genaral, representation is a way to show an actual situation using models(Goldin, 2002). Mathematics requires representations because of its abstract (Minarni \& Napitupulu, 2017). Students who are able to represent mathematical idea correctly have a good understanding of the mathematical concept. Mathematical representation can be presented visually (e.g., charts, diagrams, tables, and sketches/drawings) and non-visually (e.g., mathematical equations and models) (Boyce \& Moss, 2017; Rangkuti, 2015; Supandi et al., 2018). Presenting fractions in their simplest forms make it easier for students to understand. In general, teaching and learning fractions can be very challenging because fractions can be represented in many ways. Students will need to use their own time to find the best way for them to understand how to use fractions in problem-solving.

Using innovative learning techniques will help students to minimize any fears or misconceptions they may have about fractions. In particular students' MCU and students' MR on fractions must take priority. Therefore, allowing students to use hands-on tools to demonstrate their understanding will yield the best results (Hafiziani, 2015). In addition, the learning should be tailored by students' cognitive development level (Hafiziani, 2015). One of the innovative methods for teaching fractions is called Concrete-Pictorial-Abstract (CPA) strategy. This strategy, based on Bruner's learning theory, consists of three modes of learning: "enactive-iconic-symbolic" (Leong et al., 2015). There are three stages; (1) concrete (learning through real objects); (2) pictorial/representational (learning through image representation); and (3) abstract (learning through abstract writing). These different methods can reduce the frustration students feel while learning fractions. This strategy is highly recommended to use with elementary school students who are still in the cognitive stage of concrete learning. Using manipulative objects is very important to their understanding. 
Research results also show that CPA strategy is effective in learning mathematics. First, the research by Witzel et al. (2003) found that CPA can help children overcome any difficulties they may have in learning math. Students also make fewer errors when attempting to solve algebra problems. Second, research by Witzel (2005) concluded that CPA strategy have a positive influence on students' learning outcomes in linear algebra. Third, research conducted by Flores (2010) reported that CPA is effective for learning subtraction. Fourth, Sarfo et al. (2014) stated that the CPA strategy improves students' understanding of geometry and algebra. Fifth, Watt (2013) revealed that CPA strategy helps students to understand more complex algebra concepts. Sixth, Hafiziani (2015) reported that the CPA strategy has positive effects toward students' MR.

Based on the foregoing, it can be concluded that CPA strategy has a significant positive impact on students' conceptual understanding, learning outcomes, and MR. However, researches have not performed a study that examines if CPA strategy can improve students' MCU and MR on fractions. In addition, how CPA strategy can improve students' MCU and MR on fractions still requires empirical studies both qualitatively and quantitatively.

Therefore the focus of this study is to answer the following questions: (1) Does the CPA strategy significantly affect the students' MCU and students' MR on fractions? and (2) how can CPA strategy improve students' MCU and students' MR on fractions?

\section{METHOD}

\section{Research Design}

This research applied mixed method with a simultaneously embedded design because it has two constant objectives namely (1) to determine whether the CPA strategy has a positive impact on students' MCU and students' MR on fractions, and (2) to describe how CPA strategy can improve students' MCU and students' MR on fractions, and a combination of both questions (Creswell, 2014). The quantitative phase was an experiment using post-test only control group design as described on Table 1.

Table 1

Design of qualitative phase

\begin{tabular}{lcc}
\hline Group & Treatment & Post-Test \\
\hline $\begin{array}{l}\text { Experimental } \\
\mathrm{n}=23\end{array}$ & $\mathrm{X}$ & $\mathrm{Y}_{1}$ \\
\hline $\begin{array}{l}\text { Control } \\
\mathrm{n}=15\end{array}$ & - & $\mathrm{Y}_{2}$ \\
\hline $\mathrm{X} \quad=$ CPA strategy & & $\mathrm{Y}_{2}$ \\
$\mathrm{Y}_{1} \quad=$ Post-test of $\mathrm{MCU}$ & & \\
$\mathrm{Y}_{2}=$ Post-test of $\mathrm{MR}$ & &
\end{tabular}

Meanwhile, the qualitative phase is a descriptive approach (Memduhoğlu et al., 2017). The aim of the qualitative phase was to know how CPA strategy can affect the students' MCU and students' MR on fractions. More details about the qualitative phase is shown on Table 2. 
Table 2

Qualitative phase

\begin{tabular}{llll}
\hline Num. & \multicolumn{1}{c}{ Kind of Data } & \multicolumn{1}{c}{ Instruments } & \multicolumn{1}{c}{ Time Plot } \\
\hline 1 & Students responses & Interview sheet & At the end of research \\
\hline 2 & Group discussion activities & Observation sheet & On research process \\
\hline 3 & Students products & Notes & On research process \\
\hline
\end{tabular}

\section{Participants}

In the quantitative phase, all $3^{\text {rd }}$ graders in Padangbulia Village during academic year of $2017 / 2018$ were used as the population of the study. A cluster random sampling technique was used to identify the sample group. Two classes namely one class from SD (Elementary school or ES) Negeri 1 Padangbulia (23 students with 11 males and 12 females) and another class from SD (ES) Negeri 3 Padangbulia (15 students with 3 males and 12 females) took part in the study. All students in this study were 8 years old with a lower-middle cognitive level. The experimental and control groups were chosen at random. A t-test was uased to ensure equality. Before applying the t-test, the normality test was analyzed using Kolmogorov-Smirnov technique and their homogeneity using Levene technique (Demitra \& Sarjoko, 2018). Meanwhile, in the qualitative phase some students were intentionally chosen to participate in the study. Snowball sampling technique was used to choose this group.

\section{Instrument}

The quantitative data namely MCU and MR were collected using narrative form on fractions which consisted of 10 and 9 items, respectively. The test indicators of MCU are: (a) able to define fractions in their own words; (b) distinguish example and counterexamples of the fractions concept; and (c) use fractions correctly in various situations (NCTM, 2000). Whereas the test indicators of MR are: (a) create and use models to organize, record, and communicate mathematical ideas; (b) select, apply, and manipulate mathematical representations to solve problems; (c) use representations to model and interpret physical, social, and mathematical phenomena (NCTM, 2000). The instrument is deemed valid if it passed two critical qualities, namely validity and reliability (Hobri et al., 2018). But, two mathematics professors must approve of the representations or models. After the validity and reliability test, it was found that 9 items of MCU and 9 items of MR were valid with alpha cronbach 0.85 and 0.81 respectively. Meanwhile, for the qualitative data; (a) observation sheets were used to collect data on group discussion activities, (b) interview techniques were employed to find out students' responses to CPA strategy implementation, and (c) notes about students' answers to explain how the CPA strategy can improve the students' MCU and MR. The validity of qualitative instruments was testedusing source triangulation. It was done by interviewing mathematics teacher and dean on experimental and control class respectively as well as a professor from Ganesha University.

\section{Technique of Data Analysis}

The results of quantitative and qualitative research were analyzed separately (Creswell, 2014) as follows: 


\section{Quantitative Data Analysis}

The analysis of quantitative data was performed using the Manova test at 5\% significance level, because this research had one independent variable and two dependent variables (Akayuure et al., 2016; Caruth, 2014; Flores et al., 2014). Before doing the Manova-test, the variables of the data was tested, the homogeny of variance/covariance matrices of dependent variables, and the correlation between the dependent variables were also examined (Akayuure et al., 2016; Candiasa, 2010). The bivariate normality test was analyzed using correlation using the mahalanobis distance technique (Burdenski Jr, 2000; Demitra \& Sarjoko, 2018). Furthermore, the homogeneity test of variance-covariance matrix of dependent variables using Box'M test (Akayuure et al., 2016). Finally, the correlation between the dependent variables was tested by calculating the value of the Pearson Correlation Coefficient (Caruth, 2014).

Qualitative Data Analysis

The analysis of qualitative data was done in 3 stages, namely data reduction, presentation, and verification (Sugiyono, 2008). The final stage was carried out using the triangulation in order to assure credibility of the datay (Sugiyono, 2008). The technique of triangulation depended on the teachers' source. The interpretation of quantitative and qualitative data was compared and matched to get a comprehensive conclusion.

\section{FINDINGS}

\section{The Quantitative Findings}

Quantitative data were analyzed using SPSS software. The data were obtained from the result of post-test on the two sample groups and are presented in Table 3.

Table 3

The analysis of MCU and MR

\begin{tabular}{llllll}
\hline \multirow{2}{*}{ Num. } & \multirow{2}{*}{ Variable } & \multicolumn{3}{c}{ MCU } & \multicolumn{2}{c}{ MR } \\
\cline { 2 - 6 } & & Experiment & \multicolumn{1}{c}{ Control } & Experiment & Control \\
\hline 1. & $\mathrm{~N}$ & 23 & 15 & 23 & 15 \\
\hline 2. & $\bar{Y}$ & 20,431 & 18,366 & 14,391 & 11,86 \\
\hline 3. & SD & 1,90 & 2,29 & 2,53 & 2,40 \\
\hline
\end{tabular}

As shown in Table 3, the average of students' MCU and students' MR in experimental group is higher than those in control group. The bivariate normality test was performed showing a correlation between mahalanobis distance at $5 \%$ significance level and can be seen in Table 4. 
Table 4

Test result of multivariate normality testing

\begin{tabular}{|c|c|c|c|}
\hline \multicolumn{4}{|c|}{ Correlations } \\
\hline & & Mahalanobis Distance & Qi \\
\hline \multirow[t]{3}{*}{ Mahalanobis Distance } & Pearson Correlation & 1 & .866 \\
\hline & Sig. (2-tailed) & & .000 \\
\hline & $\mathrm{N}$ & 38 & 38 \\
\hline \multirow[t]{3}{*}{ Qi } & Pearson Correlation & .866 & 1 \\
\hline & Sig. (2-tailed) & .000 & \\
\hline & $\mathrm{N}$ & 38 & 38 \\
\hline
\end{tabular}

Based on Table 5, the significance level is 0.000 . It is smaller than the significance value of $5 \%$. So it was concluded that the data had come from a population with normal bivariate distribution. The results of the dependent variables variance/covariance matrices test are summarized in Table 5 below.

Table 5

Summary of matrices variance/covariance

\begin{tabular}{ll}
\hline & Box's Test of Equality of Covariance Matrices $^{\mathrm{a}}$ \\
\hline Box's M & .947 \\
\hline $\mathrm{F}$ & .295 \\
\hline $\mathrm{df1}$ & 3 \\
\hline $\mathrm{df} 2$ & 40667.290 \\
\hline Sig. & .829 \\
\hline
\end{tabular}

The sig. value (0.829) was greater than $5 \%$. Therefore, the variance/covariance matrices of dependent variables are homogeneous. Furthermore, product correlation was used to test the collinearity between the dependent variables. The test results are listed on Table 8.

Table 6

Summary of colinearity test between dependent variables

\begin{tabular}{lllllll}
\hline \multicolumn{7}{c}{ Correlations } \\
\hline & \multicolumn{2}{c}{ Experiment } & & Control & \\
\hline \multirow{2}{*}{ MCU } & MCU & MR & MCU & MR \\
\cline { 2 - 6 } & Pearson Correlation & 1 & .572 & 1 & .548 \\
\cline { 2 - 7 } & Sig. (2-tailed) & & .004 & & .034 \\
\cline { 2 - 7 } & $\mathrm{N}$ & 23 & 23 & 15 & 15 \\
\hline \multirow{2}{*}{ MR } & Pearson Correlation & .572 & 1 & .548 & 1 \\
\cline { 2 - 6 } & Sig. (2-tailed) & .004 & & .034 & \\
\cline { 2 - 6 } & $\mathrm{N}$ & 23 & 23 & 15 & 15 \\
\hline
\end{tabular}


From Table 6 above, it is clear that the collinearity test of student's MCU and MR in both groups showed the sig. value is greater than $5 \%$. Thus, dependent variables (MCU and MR) of both groups were significantly correlated. After all prerequisite tests were performed, with the final test was the Manova test. Here is a summary of Manova test results.

Tabel 7

Result of MANOVA test

\begin{tabular}{|c|c|c|c|c|c|c|}
\hline \multicolumn{7}{|c|}{ Multivariate Tests ${ }^{\mathrm{b}}$} \\
\hline Effect & & Value & $\mathrm{F}$ & Hypothesis df & Error df & Sig. \\
\hline \multirow[t]{4}{*}{ Intercept } & Pillai's Trace & .989 & $1556.001^{\mathrm{a}}$ & 2.000 & 35.000 & .000 \\
\hline & Wilks' Lambda & .011 & $1556.001^{\mathrm{a}}$ & 2.000 & 35.000 & .000 \\
\hline & Hotelling's Trace & 88.914 & $1556.001^{\mathrm{a}}$ & 2.000 & 35.000 & .000 \\
\hline & Roy's Largest Root & 88.914 & $1556.001^{\mathrm{a}}$ & 2.000 & 35.000 & .000 \\
\hline \multirow[t]{4}{*}{ Group } & Pillai's Trace & .274 & $6.620^{\mathrm{a}}$ & 2.000 & 35.000 & .004 \\
\hline & Wilks' Lambda & .726 & $6.620^{\mathrm{a}}$ & 2.000 & 35.000 & .004 \\
\hline & Hotelling's Trace & .378 & $6.620^{\mathrm{a}}$ & 2.000 & 35.000 & .004 \\
\hline & Roy's Largest Root & .378 & $6.620^{\mathrm{a}}$ & 2.000 & 35.000 & .004 \\
\hline
\end{tabular}

As shown in Table 7, it shows the statistical values of Pillai's Trace, Wilks'Lambda, Hotelling's Trace, and Roy's Largest Root respectively $F=6.620^{\mathrm{a}}$, and the sign. value equals 0.004 less than 0,05 . These results prove that the appropriate result is $\mathrm{H}_{1}$. This means that the students' $\mathrm{MCU}$ and $\mathrm{MR}$ in the experimental group is better than those in the control group.

\section{The Qualitative Findings}

Based on the results of interviews, it is clear that the students who were taught using CPA strategy had a deeper understanding of the material. Furthermore, students who learned with concrete objects had a more complete understanding of fractions, so the use of abstract concepts when teaching fractions should be minimized. Through demonstration and discussion, students were able to express their understanding of fractions with their own words, and to give examples. This learning strategy significantly increased the students' ability to meaningfully solve problems involving fractions. It was also found that the students' MR in the experimental group gradually increased at each meeting. The students were able to choose a meaningful depiction of fractions. They were also able to use their own words to show their understanding of fractions and how to solve problems involving them.

Furthermore, it was also observed that using concrete objects made students engage more in the learning process. When the researchers used buffalo paper and bread to represent fractions, the students responded differenly. The discussion was better when bread was used. Thus, it seems that the use of concrete object was more interesting for the students in the study. 
An example of students' discussion was recorded when a teacher divided a square image into some unequal parts and then asked the students to write the correct fractions. The dialogue of students' discussion is transcribed in Fragment 1. As the author expected, students understood the basic concept of fractions.

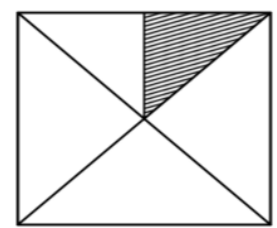

Figure 1

Example of picturial representation of a fractions

Fragment 1

$\mathrm{T}$ : Well, what is the value of fractions represented by the figure? (teacher points to the figure)

E5 : Yes, Sir... (student raised his right hand and then went to the white board)

$\mathrm{T} \quad$ : Okay, please... $\frac{1}{5}$

(E5 wrote his answer ${ }^{\overline{5}}$ and gave his explanation)

E5 : Here is a picture that divided into five parts, and then $n_{1}$ this is $\frac{1}{5}$.

E13 : I don't think so, the figure represented the fractions $\overline{8}$.

E4 : Why? Hm....I think E5 is true.

E20 : Oh,, I agree with E13. Let me explain that ( went to white board). This picture is divided into 5 parts but each part is not equal. Look at this, this part is smaller than this part, so it is not 55 .

E13: We must divide it into equal parts. So we can divide this part again into two parts. Repeating this way on this part and this part. We will get 8 equal parts, so it isE8

E5 : Hmm... what am I doing wrong?

E13: When we make a fraction we must divide a whole object into equal parts

$\mathrm{T}$ : Yes!!! You are right E13. Okay E5, what can you conclude from your discussion?

E5 : Divide the whole object into equal parts when we make fractions.

The documentation of the post-test results also supports the findings above. Here are two examples of misunderstandings about fractions still occurring in the control group presented in figures 2 and 3.

International Journal of Instruction, January $2019 \bullet$ Vol.12, No.1 


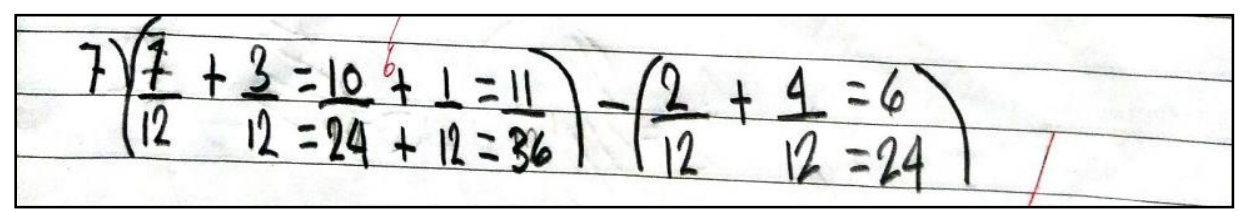

Figure 2

Misconception when operating fractions

K12 student believes that adding fractions means adding the numerator of one with the numerator of the other as well as the denominator with the denominator. She argue that $\frac{7}{12}+\frac{3}{12}$ can be transformed into $\frac{7+3}{12+12} \quad$ because "+" can be applied both to the numerator and denominator.

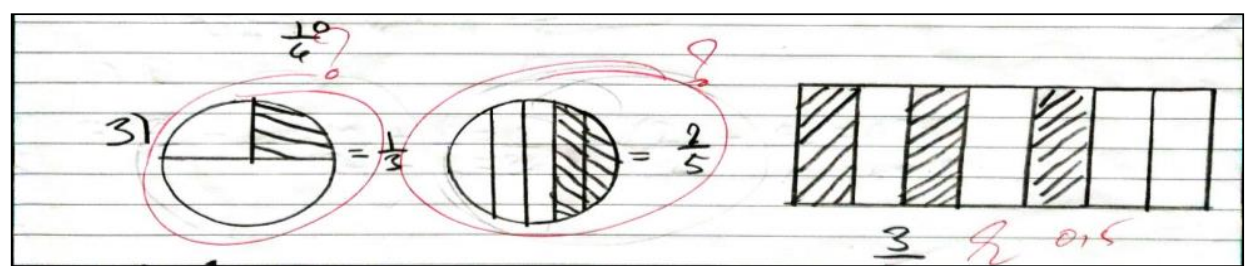

Figure 3

Errors in computing with fractions

K15 student was doing wrong to make image representation of $\frac{1}{3}$ and $\frac{2}{5}$. A more detailed interview with $\mathrm{K} 15$ revealed that still believed that fractions involved dividing up the whole object into parts. But he did not carefully understand that the portions should all be equal. He drew the circle with uneven parts making this representation inaccurate. This student's error was a result of his lack of attention to details, not practicing with real objects, and not using a variety of methods to understand fractions. This implies that the teachers often dominate the classroom and do not allow students to learn in varied methods. Meanwhile students do not have the opportunity to manipulate a variety of objects, to practice representing fractions with various images, to discuss and create .explanations as to how they formed their answers. This resulted in a misunderstanding of fractions and finding that the limitations of teaching fractions.

Furthermore, it is apparent that teaches must be careful when using a circle to demonstrate fractions. Students may find it difficult to construct a circle and then to divide it into equal parts. As the result, students often focus more on the number of segments rather than the equality of the segments themselves. The students do not fully understand the importance of the equal parts that compose the whole. Consequently, a square model or number line are more accurate depictions, and these two drawings should be used as they are easier for students to understand.

Meanwhile, the disadvantages did not occur in the experimental group. The CPA strategy seems to play significant role in preventing errors and improving understanding. The strategy of CPA provides a good opportunity for students to explore, experiment 
with a variety of representations and finally to construct an accurate understanding of the fractions.

\section{DISCUSSION}

Using the CPA strategy has a positive effect on students' MCU and students' MR on fractions. This result is consistent with Sarfo et al. (2014) which stated that the CPA strategy had a positive effect on students' conceptual understanding of geometry and algebra. Flores (2010); Watt (2013); Witzel (2005); Witzel et al. (2003) also revealed that the CPA strategy was effective for learning mathematics for students with or without a learning disability. Learning fractions using CPA strategy started by manipulating concrete objects, and using a variety of representations of fractions. This strategy helps to feel less anxious when dealing with the abstract concept of fractions. CPA strategy also correlates with the level of the cognitive development of elementary school students. However, it does not rule out the possibility that CPA strategy is effective middle and high school students (Hafiziani, 2015).

Using manipulative object gradually helps to strengthen students' MR ability. This process helps students understand the truth about fractions. On other hand, increasing students' interaction in the class while learning may allow students to use and develop procedural steps more accurately (Witzel, 2005). The development of students' MCU and students' MR skills directly positively impacted their problem solving and learning outcomes. This was consistent with Cease-Cook (2013) that reported that CPA strategy is effective for improving students' ability to solve inverse function problems. Flores (2010) also reported that CPA has a positive effect on students' ability to master the concept of subtraction.

In addition, students were more motivated and more enthusiastic during the discussion process. This is because manipulating concrete objects may help students understand that fractions were applicable to real life (Hafiziani 2015). Students immediately feel the benefits of learning fractions to solve real life problems (Hafiziani 2015).

Other findings also indicate that students were able to communicate their understanding using their own words. Students were more confident discussing their reasons and explanations. Students used to tell and write the process during the concrete phase, thus it can their memories and sharpen their understanding. During this process, students are required to be able to think creatively when problem solving. Furthermore, they also know and understand the complexity of a concept in order to get the right solution. These findings are also supported by Sudiarta et.al (2018) and Sukawijaya \& Sudiarta (2018) which stated that the students' discussion was able to create very significant mathematical proficiency (conceptual understanding, procedural fluency, strategic competence, adaptive reasoning, productive disposition) and communication skills (clarification, advice).

The enthusiasm of students of students learning fractions was positively impacted second stage of the CPA strategy. The students learn fractions by experiencing a variety of image representations. Students create images according to the actual form of 
concrete object that they understood. Because they are $3^{\text {th }}$ graders, they mostly prefer to draw, especially colorful pictures

Regardless of the results, as well as some other things mentioned earlier, we should also explain the challenges and difficulties teachers faced in implementing CPA strategies in the context of this research such as the difficulties using real objects, time required, and especially finding objects that are not suitable for learning.

\section{CONCLUSION}

Based on the results of research, it can be concluded that the CPA strategy has significantly affected the students' MCU and students' MR on fractions. The CPA strategy improved students' MCU and students' MR in which it provided students (1) the ability to explore and experience fractions, (2) to become more motivated and eagerwhen learning, (3) to be more enthusiastic when expressing ideas in their own words and reasoning, (4) to be more able to communicate their findings, (5) to get better results answering fractions problems.

\section{RECOMMENDATIONS}

Based on the results, mathematics teachers should use CPA strategy as one of the more innovative teaching styles to young children in elementary school as well as middle school, in order to provide students more opportunity in exploring and experiencing the mathematical concept. But, it is recommended that this experiment be conducted using larger samples and with more materials.

\section{REFERENCES}

Akayuure, P.; Asiedu-Addo, \& Alebna, V. (2016). Investigating the effect of origami instruction on preservice teachers' spatial ability and geometric knowledge for teaching. International Journal of Education in Mathematics, Science and Technology, 4(3), 198208. Retrieved 29 April, 2018 from https://doi.org/10.18404/ijemst.78424.

Burdenski Jr, T. K. (2000). Evaluating univariate, bivariate, and multivariate normality using graphical procedures. USA: Texas A\&M University.

Candiasa, I. M. (2010). Statistik Univariat dan Bivariat Disertai Aplikasi SPSS. Singaraja: University of Pendidikan Ganesha.

Caruth, G. D. (2014). A multivariate analysis (MANOVA) of where adult learners are in higher education. International Journal of Learning, Teaching and Educational Research, 1(1), 93-107.

Cease-Cook, J. J. (2013). The Effects of Concrete-Representational-Abstract sequence of instruction on solving equations using inverse operations with high school students with mild intellectual disability. Dissertation. The University of North Carolina.

Creswell, J. W. (2014). Research design: qualitative, quantitative, and mixed methods approaches (4th ed). Thousand Oaks: SAGE Publications. 
Demitra, \& Sarjoko. (2018). Effects of handep cooperative learning based on indigenous knowledge on mathematical problem solving skill. International Journal of Instruction, 11(2), 103-114. Retrieved 7 May, 2018 from https://doi.org/10.12973/iji.2018.1128a.

Edo, S. I. \& Samo, D. D. (2017). Learning trajectory of fractions using realistic mathematics context of traditional game SIKI DOKA. Journal "Mosharafa", 6/3, 311322.

Flores, M. M. (2010). Using the Concrete-Representational-Abstract Sequence to teach subtraction with regrouping to students at risk for failure. Remedial and Special Education, 31/3, 195-207. Retrieved 27 August, 2017 from https://doi.org/10.1177/0741932508327467.

Flores, M. M.; Thornton, J.; Franklin, T. M.; Hinton, V. M. \& Strozier, S. (2014). Elementary general and special education teachers' mathematics skills and efficacy. Journal of Research in Education, 24(1), 69-82.

Goldin, G. A. (2002). Representation in mathematical learning and problem solving. In L. D. English (Ed.), Handbook of international research in mathematics education.

Mahwah, NJ: Lawrence Erlbaum Associates, Publishers.

Hafiziani. (2015). The influence of Concrete Pictorial Abstract (CPA) approach to the mathematical representation ability achievement of the pre-service teachers at elementary school. International Journal of Education and Research, 3(6), 113-126. Retrieved 27 August, 2017 from http://ijern.com/journal/2015/June-2015/09.pdf.

Hobri, H.; Dafik, D. \& Hossain, A. (2018). The Implementation of Learning Together in Improving Students' Mathematical Performance. International Journal of Instruction, 11/2, 483-496. Retrieved 7 May, 2018 from https://doi.org/10.12973/iji.2018.11233a.

Khuriyati, L. (2015). Desain pembelajaran operasi pecahan menggunakan kertas berpetak di Kelas IV. Journal of Sriwijaya University, 2(2), 104-114.

Leong, Y. H.; Ho, W. K. \& Cheng, L. P. (2015). Concrete-Pictorial-Abstract: Surveying its origins and charting its future. The Mathematics Educator, 16(1), 1-19.

Memduhoğlu, H. B.; Kotluk, N. \& Yayla, A. (2017). The effect of focus group discussions on pre-service teachers' teaching experiences and practices: A mixed methods study. International Journal of Instruction, 10(4), 273-292. Retrieved 6 May, 2018 from https://doi.org/10.12973/iji.2017.10416a

Minarni, A., \& Napitupulu, E. E. (2017). Developing Instruction Materials Based on Joyful PBL to Improve Students Mathematical Representation Ability. International Education Studies, 10(9), 23. https://doi.org/10.5539/ies.v10n9p23

NCTM (Ed.). (2000). Principles and standards for school mathematics. Reston, VA: National Council of Teachers of Mathematics. 
Prayitno, A. \& Wulandari, D. T. (2015). Meminimalkan kesalahan konsep pecahan melalui pembelajaran penemuan terbimbing dengan gesture produktif pada siswa SMP. Jurnal Pendidikan Matematika, 1(2), 106-117.

Sadra, I. W. (2013). Metodologi pembelajaran matematika. Singaraja: Universitas Pendidikan Ganesha.

Sarfo, F. K.; Eshun, G.; Elen, J. \& Adentwi, K. I. (2014). Towards the solution of abysmal performance in mathematics in junior high schools: Comparing their pedagogical potential of two designed interventions. Electronic Journal of Research in Educational Psycology, 12(3), 763-784.

Sudiana, I.W.; Japa, G. N. \& Suarjana, M. (2006). Matematika II. Singaraja: Universitas Pendidikan Ganesha.

Sudiarta, I. G. P.; Sukajaya, I. N. \& Suharta, I. G. P. (2018). Investigation on students' mathematical online discussion: A case study in grade 8 SMPN 1 Denpasar. International Conference on Mathematics and Natural Sciences (IConMNS 2017) J. Phys.: Conf. Ser. 1040. 012031.

Sugiyono. (2008). Metode penelitian pendidikan. pendekatan kualitataif, kuantitatif, dan $R \& D$. Bandung: Alfa Betta.

Suharta, I. G. P. (2004). Pembelajaran pecahan di sekolah dasar dengan menggunakan pendekatan matematika realistik. Dissertation. University of Negeri Surabaya.

Sukawijaya, I. M. G. \& Sudiarta, I.G. P. (2018). Developing blended learning environment to improve learning performance and self-reliance for junior high school students. International Conference on Mathematics and Natural Sciences (IConMNS 2017) J. Phys.: Conf. Ser. 1040. 012030.

Supandi, S., Waluya, S. B., Suyitno, H., \& Dewi, K. (2018). Think-Talk-Write Model for Improving Students' Abilities in Mathematical Representation. International Journal of Instruction, 11(3), 77-90. https://doi.org/10.12973/iji.2018.1136a

Watt, S. J. (2013). Teaching algebra-based concepts to students with learning disabilities: The effects of pre-teaching using a gradual instructional sequence. Dissertation. University of Iowa.

Witzel. (2005). Using CRA to teach algebra to students with math difficulties in inclusive settings. Learning Disabilities: A Contemporary Journal, 3(2), 49-60.

Witzel, B. S.; Mercer, C. D. \& Miller, M. D. (2003). Teaching algebra to students with learning difficulties: An investigation of an explicit instruction model. Learning Disabilities Research \& Practice, 18(2), 121-131.

Wijaya, A. (2017). The relationships between Indonesian fourth graders' difficulties in fractions and the opportunity to learn fractions: A snapshot of TIMSS results. International Journal of Instruction, 10(4), 221-236. Retrieved 7 May, 2018 from https://doi.org/10.12973/iji.2017.10413a. 
Zabeta, M.; Hartono, Y. \& Putri, R. I. I. (2015). Desain pembelajaran materi pecahan menggunakan pendekatan PMRI di kelas VII. Journal of Beta 2015, 8/1, 86-99. 